\title{
Synthesizing Normal and Non-Normal Modal Logics in Philosophical Epistemology Axiomatic System Modeled by the Logic Square and Hexagon of Opposition
}

\author{
Vladimir O. Lobovikov \\ Institute of Pholosophy and Law of RAS(UB) \\ 16 Sofya Kovalevskaya Str., Yekaterinburg, \\ 620990, Russia
}

Received 29.04.2019, received in revised form 06.05.2019, accepted 09.05.2019

The paper aims at coping with the difficult problem of rationally uniting astonishingly huge amount of qualitatively different modal logics. For realizing this aim artificial languages of symbolic logic and the axiomatic methodology are used. Therefore, the method of constructing and studying formal logic inferences within the axiom system under investigation is exploited systematically. Inventing and elaborating a hitherto not-considered axiomatic system of epistemology uniting normal and not-normal modal logics is the new nontrivial scientific result of this work. History of philosophy and systematical philosophy, formal ethics and formal aesthetics, philosophical epistemology and analytical theology, philosophy of law and philosophy of science are among the important fields of application of the nontrivial abstracttheoretic principles demonstrated in this paper. Using the above-indicated machinery the author has arrived to the following main conclusion: the famous philosophical principles of utilitarianism, hedonism, optimism, pragmatism, fideism, falsifiability, verifiability, "Hume's Guillotine", "naturalistic fallacies" et al have not absolutely indefinite (unlimited) but quite definite (limited) sphere of relevant applicability; the precise formal definition of the borderline of mentioned sphere of relevance is the axiomatic one submitted and discussed in the paper. This general conclusion is instantiated in the text by several particular conclusions concerning explication and clarification of specific philosophical ideas and principles, for example, the one of kalokagathia. The author concludes that constructing and investigating the axiomatic systems of universal philosophical epistemology is indispensable for adequate representing human knowledge in artificial intellectual systems, for instance, in autonomous AI-robots.

Keywords: normal, non-normal, modal, universal, logic, a-priori, a-posteriori, knowledge, axiomatic-system, square-and-hexagon-of-opposition.

Research area: philosophy.

(c) Siberian Federal University. All rights reserved

* Corresponding author E-mail address: vlobovikov@mail.ru

This work is licensed under a Creative Commons Attribution-NonCommercial 4.0 International License (CC BY-NC 4.0). 
Citation: Lobovikov, V.O. (2019). Synthesizing normal and non-normal modal logics in philosophical epistemology axiomatic system modeled by the logic square and hexagon of opposition. J. Sib. Fed. Univ. Humanit. soc. sci., 12(5), 894-907. DOI: 10.17516/1997-1370-0336.

\section{Introduction}

Nowadays one had better talk not of logic but of logics as today "logic" is not the unique tool for reasonable thinking but a very big box staffed by an infinite set of different thought-tools to be used in different conditions for different goals. As there is an astonishingly huge amount of qualitatively different patterns of rational reasoning the hard problem arises: how can an intelligent agent (thought subject) be an individual (i. e. not divided). The absolute split of consciousness can be a hard mental-problem for human creatures. How can one make the consciousness division not absolute but relative (somehow controlled)? The movement in philosophy of logic aimed at finding a reasonable answer to this knotty but very important question is called "Universal Logic". Many logicians in many countries are involved in this movement. For example, today one of its well-known scientific investigation centers is in Brasil and one of its well-known leaders (recognized all over the world) is J.-Y. Béziau. He and his colleagues living in different countries created a new scientific journal called "Logica Universalis" and initiated the ongoing process (system) of intellectually respectable and representative world congresses called "Universal Logic". The congresses venues; Montreux, Switzerland (2005); Xi'an, China (2007); Lisbon, Portugal (2010); Rio de Janeiro, Brazil (2013); Istanbul, Turkey (2015), Vichy, France (2018). The quite clear and well-elaborated answer to the question "What is Universal Logic?" is given in (Béziau, 2017). The indicated scientific trend in developing philosophy of logic has produced several interesting results but some significant philosophical and technical problems still remain not solved. One of them is studied and discussed in this article.

\section{Theoretical framework}

The article is written within the general conceptual framework called the "analytical philosophy" in the wide meaning of the term. Hence accurate analysis of natural and artificial language fragments is essential to this research work. Another significant aspect of the paper's theoretical framework is its belonging to the old philosophical tradition of studying various modalities which tradition is well-known since times of Aristotle. Today modality studies are well-represented by plenty of symbolic modal logics (alethic, epistemic, deontic, utilitarian, axiological, et al). The 
paper deals with the mentioned symbolic modal logics essentially. Also, the article idea moves within the theoretical framework of the significant distinction between normal and non-normal modal logics which distinction was initially submitted and discussed by (Kripke, 1963; 1965). One more theoretical framework within which my thought moves in this paper is the old idea of square of opposition (or logic square) developed in $20^{\text {th }}$ century by R. Blanché into the hexagon of opposition (Blanché, 1957; 1966). Further developing R. Blanché's conception, J.-Y. Béziau invented a more sophisticated octagon of opposition of alethic modalities. The fundamental generalization process went on and in result today various $\mathrm{N}$-gons of opposition are invented and discussed in different fields of human knowledge and culture in general. This promising scientific trend (graphic modeling logical structures of conceptual knowledge systems) headed nowadays by J.-Y. Béziau \& Colleagues is represented by the ongoing process (system) of intellectually respectable and representative world congresses called "Square of Opposition" The congresses venues; - Montreux, Switzerland, in 2007; Corté, Corsica, in 2010; Beirut, Lebanon, in 2012; Vatican, in 2014; Easter Island, Chile, in 2016. The present article of mine is also located within the Square-and-Hexagon-of-Opposition theoretical framework as it submits an option of Squaring and Hexagonizing the axiomatic system of universal philosophical epistemology under discussion.

\section{Statement of the problem}

From the above general introduction, the following particular concrete problem follows. The system of rational (a-priori) knowledge of necessary truths is organized by the normal modal logic; the system of empirical (a-posteriori) knowledge of contingent truths is organized by the not normal modal logic. It is rational to expect that human knowledge in general (as a whole) is a consistent union of a-priori and a-posteriori knowledge. But simple conjunction of normal and not-normal modal logics makes up a logic contradiction. This is a concrete problem to be solved in this paper.

\section{Methods}

For solving the above-indicated problem in this paper the artificial language of symbolic modal logic and the axiomatic deductive method are exploited systematically. The distinction between the meta-language and the object-language is used and the alphabets are fixed. The notion of well-formed formula is explicated. All meanings of novel symbols and all new notions are defined manifestly. Formal proofs of theorems and formal deductive inferences from assumptions are represented as finite 
successions of formulae. Thus, in this paper the syntax method of investigating is used. However along with the syntactic constructions and transformations of symbolsuccessions the content-analysis methods (creating philosophical interpretations) is utilized as well.

\section{Discussion}

As in the present paper the main method of investigating is the syntax one let us start with manifest precise definitions of meanings of the artificial language symbols to be used hereafter. Below the logic symbols $\rightarrow, \leftrightarrow, \&, \vee, \neg$ stand for the classical propositional logic operations "implication", "equivalence", "conjunction", "disjunction (non-excluding one)", "negation", respectively. Letters $\mathbf{p}, \mathbf{q}, \mathbf{r}, \ldots$ (belonging to the object-language) stand for the elementary propositions. An axiomatic epistemology system $\Xi$ to be constructed and discussed in this article contains all formulae, axioms and inference-rules of the classical propositional logic. Symbols $\alpha$ and $\beta$ (belonging to meta-language) stand for any formulae of $\Xi$. Additional formulae of $\Xi$ are obtained by the following rule: if $\alpha$ is a formula of $\Xi$ then $\Psi \alpha$ is a formula of $\Xi$ as well. The symbol $\Psi$ belonging to meta-language stands for any element of the set of modalities $\{\square, \mathbf{K}, \mathbf{A}, \mathbf{E}, \mathbf{S}, \mathbf{T}, \mathbf{F}, \mathbf{P}, \mathbf{Z}, \mathbf{G}, \mathbf{O}, \mathbf{B}, \mathbf{U}, \mathbf{Y}, \mathbf{J}\}$. Symbol stands for the alethic modality "necessary". Symbols K, A, E, S, T, F, P, Z, respectively, stand for modalities "agent knows that...", "agent a-priori knows that...", "agent a-posteriori knows that...", "under some conditions in some space-and-time a person (immediately or by means of some tools) sensually perceives (has sensual verification) that..." "it is true that...", "agent believes that...", "it is provable that...", "there is an algorithm (a machine could be constructed) for deciding that...".

Symbols $\mathbf{G}, \mathbf{O}, \mathbf{B}, \mathbf{U}, \mathbf{Y}, \mathbf{J}$, respectively, stand for modalities "it is (morally) good that...", "it is obligatory that ...", "it is beautiful that ...", "it is useful that ...", "it is pleasant that ..." "it is joyful that ...". Meanings of the mentioned symbols are defined by the following schemes of own-axioms of epistemology system $\Xi$ which axioms are added to the axioms of classical propositional logic. Schemes of axioms and inference rules of the classical propositional logic are applicable to all formulae of $\Xi$ (including the additional ones).

Axiom scheme AX-1: $\mathbf{A} \alpha \rightarrow(\square \beta \rightarrow \beta)$.

Axiom scheme AX-2: $\mathbf{A} \alpha \rightarrow(\square(\alpha \rightarrow \beta) \rightarrow(\square \alpha \rightarrow \square \beta))$.

Axiom scheme AX-3: A $\alpha \leftrightarrow(\mathbf{K} \alpha \&(\square \alpha \& \square \mathbf{S} \alpha \& \square(\beta \leftrightarrow \Omega \beta))$.

Axiom scheme AX-4: $\mathbf{E} \alpha \leftrightarrow(\mathbf{K} \alpha \&(\neg \square \alpha \vee \neg \square \neg \mathbf{S} \alpha \vee \neg \square(\beta \leftrightarrow \Omega \beta)))$. 


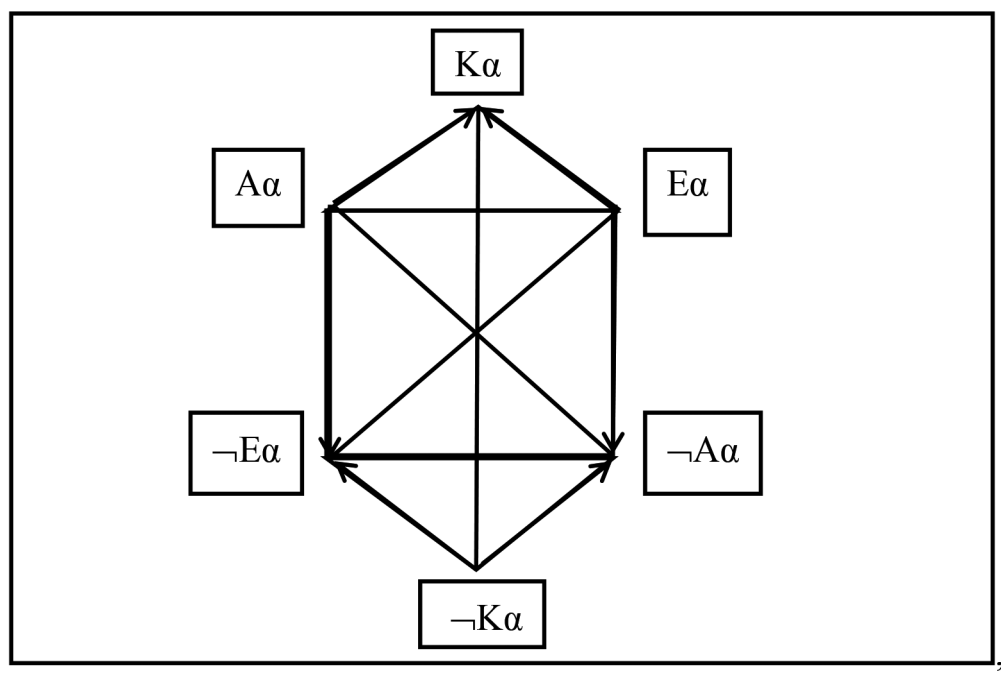

Fig. 1. Synthesizing rationalism and empiricism in one conceptual scheme

In AX-3 and AX-4, the symbol $\Omega$ (belonging to the meta-language) stands for any element of the set $\mathfrak{R}=\{\square, \mathbf{T}, \mathbf{F}, \mathbf{P}, \mathbf{Z}, \mathbf{G}, \mathbf{O}, \mathbf{B}, \mathbf{U}, \mathbf{Y}, \mathbf{J}\}$. Let elements of $\mathfrak{R}$ are called "perfection-modalities" or simply "perfections".

According to the above-submitted axiom-schemes, the system of logical interrelations among the modalities $\mathbf{K} \boldsymbol{\alpha}, \mathbf{A} \boldsymbol{\alpha}, \mathbf{E} \boldsymbol{\alpha}, \neg \mathbf{A} \boldsymbol{\alpha}, \neg \mathbf{E} \boldsymbol{\alpha}, \neg \mathbf{K} \boldsymbol{\alpha}$ is modeled by the following square-and-hexagon (Fig. 1).

In this hexagon: the contrariety relation between $\mathbf{A} \boldsymbol{\alpha}$ and $\mathbf{E} \boldsymbol{\alpha}$ is modeled by the upper horizontal line; the sub-contrariety relation between $\neg \mathbf{A} \boldsymbol{\alpha}$ and $\neg \mathbf{E} \boldsymbol{\alpha}$ is modeled by the bottom horizontal line; the contradictoriness relations between elements of the couples: $\langle\mathbf{A} \boldsymbol{\alpha}, \neg \mathbf{A} \boldsymbol{\alpha}>$; $<\mathbf{E} \boldsymbol{\alpha}, \neg \mathbf{E} \boldsymbol{\alpha}>$; $<\mathbf{K} \boldsymbol{\alpha}, \neg \mathbf{K} \boldsymbol{\alpha}>$ are modeled by the lines crossing the square. The relations of logic consequence (entailment) are modeled by arrows. My invention of this epistemological interpretation of the square-and-hexagon (Lobovikov, 2016a; 2016b) was inspired by intellectually respectable and heuristically significant works of (Béziau, 2012a; 2012b) and (Blanché, 1957; 1966).

The axiomatic system $\Xi$ is a result of significant complementation, explication, generalization and reformulation of the axiomatic system submitted originally in (Lobovikov, 2016a). That original system contained the following axioms AX-1 and AX-2 which can be derived as theorems in $\Xi$.

Axiom AX-1: Ap $\leftrightarrow(\mathbf{K p} \wedge \square \mathbf{p} \wedge \neg \mathbf{S p} \wedge \square(\mathbf{p} \leftrightarrow \square \mathbf{p}) \wedge \square(\mathbf{p} \leftrightarrow \mathbf{T p}) \wedge \square(\mathbf{p} \leftrightarrow \mathbf{P p}) \wedge$ $\square(\mathbf{p} \leftrightarrow \mathbf{F p}) \wedge \square(\mathbf{p} \leftrightarrow \mathbf{Z p}) \wedge \square(\mathbf{p} \leftrightarrow \mathbf{O p}) \wedge \square(\mathbf{p} \leftrightarrow \mathbf{G p}))$

Axiom AX-2: Ep $\leftrightarrow(\mathbf{K p} \wedge(\neg \square \mathbf{p} \vee \diamond \mathbf{S p} \vee \neg \square(\mathbf{p} \leftrightarrow \square \mathbf{p}) \vee \neg \square(\mathbf{p} \leftrightarrow \mathbf{T p}) \vee \neg \square(\mathbf{p} \leftrightarrow$ Pp) $\vee \neg \square(\mathbf{p} \leftrightarrow \mathbf{F p}) \vee \neg \square(\mathbf{p} \leftrightarrow \mathbf{Z p}) \vee \neg \square(\mathbf{p} \leftrightarrow \mathbf{O p}) \vee \neg \square(\mathbf{p} \leftrightarrow \mathbf{G p}))$ 
In these axioms $\mathbf{p}$ stands for a proposition and $\diamond \mathbf{p}$ is an abbreviation of $\neg \square \neg \mathbf{p}$. In the present paper using the meta-language symbol $\Omega$ has made it possible to make formulations of the axiom schemes AX-3 and AX-4 much more simple and compact than the corresponding too long and complicated axioms AX-1 and AX-2 of the original system.

It is worth mentioning that $(\square \alpha \rightarrow \alpha)$ and $(\mathbf{K} \alpha \rightarrow \alpha)$ are not provable in $\Xi$. Instead of them, respectively, $\mathrm{A} \alpha \rightarrow(\square \alpha \rightarrow \alpha)$ and $\mathrm{A} \alpha \rightarrow(\mathrm{K} \alpha \rightarrow \alpha)$ are provable in $\Xi$. Moreover, Gödel's necessitation rule does not belong to the set of inference rules of $\Xi$. Hence the logic underlying the system $\Xi$ is not a normal modal logic [Kripke 1963; 1965; Priest 1992; 2008; Bull, Segerberg 1984]. Moreover, in general, the inferencerule of elimination of $\square$ does not belong to the set of inference-rules of $\Xi$. Nevertheless, under the condition, that $\mathbf{A} \alpha$ (but not in general) the following inference-rule of $\square$-elimination is valid: "If $A \alpha \mid-\square \beta$, then $A \alpha \mid-\beta$ ". The below short succession of formulae-schemes demonstrates this limited inference-rule.

1) $\mathrm{A} \alpha \rightarrow(\square \beta \rightarrow \beta):$ axiom scheme $\mathrm{AX}-1$.

2) A $\alpha$ : assumption.

3) $(\square \beta \rightarrow \beta$ ): from 1 and 2 by modus ponens.

4) $\mathrm{A} \alpha \mid-(\square \beta \rightarrow \beta): 1)-3)$.

5) $\mathrm{A} \alpha \mid-\square \beta$ is given.

6) $\mathrm{A} \alpha \mid-\beta$ : from 4) -5) by modus ponens.

7) If $\mathrm{A} \alpha \mid-\square \beta$, then $\mathrm{A} \alpha \mid-\beta: 1)-6)$.

Moreover it is easy to demonstrate in $\Xi$ that under the condition that $\mathbf{A} \alpha$ (but not in general), the following (limited) inference-rule of necessitation is valid: "If A $\alpha$ $\beta$, then $A \alpha \mid-\square \beta$ ”. The following inference is a demonstration of this rile.

1. AX-3.

2. A $\alpha$ : assumption.

3. $\mathbf{K} \alpha \boldsymbol{\&} \square \alpha \boldsymbol{\&} \square \neg \mathbf{S} \alpha \boldsymbol{\&} \square(\beta \leftrightarrow \Omega \beta)$ : from 1 and 2 by propositional logic.

4. $\square(\beta \leftrightarrow \Omega \beta)$ : from 3 by the rule of $\&$-elimination.

5. $(\beta \leftrightarrow \Omega \beta)$ : from 4 by the (limited) rule of $\square$-elimination.

6. $\mathrm{A} \alpha \mid-(\beta \leftrightarrow \Omega \beta)$ : by $1-5$.

7. $A \alpha \mid-(\beta \leftrightarrow \square \beta)$ : from 6 by substituting $\square$ for $\Omega$.

8. $A \alpha \mid-\beta$ is given.

9. $\mathrm{A} \alpha \mid-\square \beta$ from 7 and 8 by propositional logic.

10. If $A \alpha \mid-\beta$ then $A \alpha \mid-\square \beta$ : by $1-9$.

Within $\Xi$ it is possible to prove the following meta-theorem (scheme of theorems). 
META-THEOREM: For any elements $\Phi$ and $\Sigma$ of the set of perfection-modalities $\Re$ the formula-scheme $(\mathrm{A} \alpha \rightarrow(\Phi \alpha \leftrightarrow \Sigma \alpha))$ is a scheme of theorems. The following succession of formula-schemes is proving this meta-theorem in $\Xi$.

1. AX-3.

2. $\mathbf{A} \alpha \rightarrow(\mathbf{K} \alpha \&(\square \alpha \boldsymbol{\&} \square \neg \mathbf{S} \alpha \boldsymbol{\&} \square(\beta \leftrightarrow \Omega \beta))$ : from 1 by elimination of $\leftrightarrow$.

3. A $\alpha$ : assumption.

4. (Ko \& $(\square \alpha \boldsymbol{\&} \square \neg \mathbf{S} \alpha \boldsymbol{\&} \square(\beta \leftrightarrow \Omega \beta))$ : from 2 and 3 by modus ponens.

5. $\square(\beta \leftrightarrow \Omega \beta)$ : from 4 by elimination of $\&$.

6. $(\beta \leftrightarrow \Omega \beta)$ : from 5 by elimination of $\square$.

7. $(\alpha \leftrightarrow \Sigma \alpha)$ : from 6 by substitution ( $\alpha$ for $\beta$, and $\Sigma$ for $\Omega$ ).

8. $(\alpha \leftrightarrow \Phi \alpha)$ : from 6 by substitution ( $\alpha$ for $\beta$, and $\Phi$ for $\Omega$ ).

9. $(\Phi \alpha \leftrightarrow \alpha)$ : from 8 by commutative-ness of $\leftrightarrow$.

10. $(\Phi \alpha \leftrightarrow \Sigma \alpha)$ : from 9 and 7 by transitive-ness of $\leftrightarrow$.

11. $\mathbf{A} \alpha \rightarrow(\Phi \alpha \leftrightarrow \Sigma \alpha)$ : from 1-10 by introduction of $\rightarrow$.

From the purely technical viewpoint the proof of this meta-theorem is not interesting (too simple). But from the philosophical-content-analysis viewpoint this meta-theorem is very interesting and nontrivial one. Various specific instances (particular cases) of this meta-theorem are well-known as fundamental philosophical principles. For example:

1) Ap $\rightarrow(\mathbf{G p} \leftrightarrow \mathbf{B p})$ : the principle of kalokagathia represented by Socrates, Xenophon, Plato, Aristotle (Lobovikov 2016c);

2) $\mathrm{Ap} \rightarrow(\mathbf{B p} \leftrightarrow \mathbf{U p})$ : the principle of beauty of useful.

3) Ap $\rightarrow(\mathbf{G p} \leftrightarrow \mathbf{U p})$ : the principle of utilitarianism ethics (Bentham, Mill);

4) $\mathrm{Ap} \rightarrow(\mathbf{G p} \leftrightarrow \mathbf{Y p})$ : the principle of hedonism in ethics (Aristippus, Epicurus);

5) $\mathrm{Ap} \rightarrow(\mathbf{B p} \leftrightarrow \mathbf{Y p})$ : the principle of hedonism in aesthetics;

6) Ap $\rightarrow(\mathbf{G p} \leftrightarrow \mathbf{T p})$ : the principle of ethic optimism (Malebranche, Leibniz);

7) Ap $\rightarrow(\mathrm{Tp} \leftrightarrow \mathbf{P p})$ : the principle of rationalistic epistemology optimism exemplified by Leibniz, Hilbert (Lobovikov 2016d);

8) $\mathrm{Ap} \rightarrow(\mathbf{P p} \leftrightarrow \mathbf{Z} \mathbf{p})$ : the principle of mechanistic (algorithmic) epistemology optimism (Lull, Leibniz);

9) $\mathrm{Ap} \rightarrow(\mathbf{T p} \leftrightarrow \mathbf{U p})$ : the principle of pragmatism in Peirce-James-Dewey theory of truth (Lobovikov 2017a);

10) Ap $\rightarrow(\mathbf{T p} \leftrightarrow \mathbf{F p})$ : the principle of fideism in theory of truth;

11) Ap $\rightarrow(\mathbf{T p} \leftrightarrow \mathbf{B p})$ : the principle of beauty as a criterion of truth;

12) Ap $\rightarrow(\mathbf{P p} \leftrightarrow \mathbf{B p})$ : the principle of beauty as a criterion of proof; 
13) Ap $\rightarrow(\mathbf{T p} \leftrightarrow \mathbf{O p})$ : the principle of normativity of truth;

14) Ap $\rightarrow(\mathbf{P p} \leftrightarrow \mathbf{O p})$ : the principle of normativity of proof;

15)Ap $\rightarrow(\mathbf{B p} \leftrightarrow \mathbf{O p})$ : the principle of normativity of beauty;

16) Ap $\rightarrow(\square \mathbf{p} \leftrightarrow \mathbf{O p})$ : the Natural-Law principle of equivalence of alethic and deontic modalities (Lobovikov, 2016b; 2016e; 2017b; 2017c);

17) Ap $\rightarrow(\square \mathbf{p} \leftrightarrow \mathbf{G p})$ : the Natural-Law principle of equivalence of alethic and axiological modalities (Lobovikov, 2016b; 2016e; 2017b; 2017c);

18) Ap $\rightarrow(\square \mathbf{p} \leftrightarrow \square \mathbf{G p})$ : the principle of Natural-Law represented by Aristotle, Ulpian, Paul, Aquinas (Lobovikov, 2016b; 2016e; 2017b; 2017c);

19) Ap $\rightarrow(\square \mathbf{p} \leftrightarrow \square \mathbf{O p})$ : the principle of Natural-Law represented by Cicero, Kant, Kelsen (Lobovikov, 2016b; 2016e; 2017b; 2017c).

20) Ap $\rightarrow(\square \mathbf{O p} \leftrightarrow \square \mathbf{G p})$ : the principle of Natural-Law.

21) $\mathrm{Ap} \rightarrow(\mathbf{O p} \leftrightarrow \mathbf{G p})$ : the principle of Natural-Law.

The list of such fundamental philosophical principles is open. However, it is important to emphasize that according to this paper all these principles have precisely defined significantly limited domain of relevant application, namely, they are adequate under the condition that Ap. Under the condition that $\mathbf{E p}$ these principles are not valid. Thus in $\Xi$ there is a room for the world as a totality of facts (=contingent truths), i. e. the world of "Tractatus" (Wittgenstein, 1994). Moreover in $\Xi$ there is a room for the falsifiability principle of scientific (empirical) knowledge (Popper, 1989; 1992) which principle is represented by the disjunct $\neg \square \alpha$ in the axiom-scheme AX-4.

If one concentrates entirely on the E-corner of the above logic square the one easily comprehends philosophical doctrines by the empiricist-minded thinkers, for instance, (Locke, 1994), (Berkeley, 1994), (Hume, 1977; 1994), (Mill, 1979; 1994), (Mach, 1984), (Moore, 2004), (Popper, 1989; 1992), (Kelsen, 1945; 1959; 1974; 1991; 1992; 2002). If one concentrates entirely on the A-corner of the above logic square the one easily comprehends the rationalistic doctrines of metaphysics by Parmenides, (Plato, 1994), (Aristotle, 1994), (Aquinas, 1928; 1994), (Descartes, 1994a; 1994b; 1994c; 1994d), (Spinoza, 1994), (Leibniz, 1903; 1952; 1971; 1982). However, if the one looks at the above logic square as a whole the one sees that the mentioned outstanding thinkers have fulfilled different parts of the work indispensable for mankind culture.

\section{Conclusion}

Summarizing the above-said I would like to emphasize the following. According to outcomes of my investigations any really intelligent autonomous system (either natural 
or artificial - it does not matter) has to have two relatively independent subsystems of different kinds of knowledge, namely, the metaphysical (a-priori) and the empirical (a-posteriori). Under some conditions for some goals the two subsystems operate separately but there are relations in which the two subsystems make up the really intelligent system as a whole. Consequently, if a system does not have either empirical or metaphysical knowledge the system is not really intelligent autonomous one (natural or artificial - it does not matter). In particular, really autonomous AI-robots have adequately to operate in both a-priori and empirical knowledge subsystems making up their knowledge as a whole. The system of their knowledge as a whole is adequately represented by the square and hexagon of opposition. This graphic model represents the transcendental unity of apperception, the unity of knowledge of really intelligent autonomous system. Thus, the split of knowledge and intelligence into the two different parts is not absolute but relative.

Nevertheless, for some goals under some conditions it is effective and convenient to reduce the difficulty of knowledge-representation-problems by dividing them into isolated parts and solving separately part by part. Applying this effective strategy to results of this paper one can see that the difficulties of investigations targeted at human knowledge representation in artificial intelligent systems ought to be reduced by dividing the investigations into the two independent branches: (1) representation of empirical (a-posteriori) knowledge; (2) representation of metaphysical (a-priori) knowledge. It is worth taking into an account that nonbeing of success in the branch (2) of investigations means nonbeing of success in solving the problem as a whole. Therefore, the problem of adequate representing human metaphysical (a-priori) knowledge in artificial autonomous systems (for example, in autonomous AI-robots) is to be taken seriously.

Obviously, the human metaphysical knowledge existing in form of texts written in natural human languages cannot be represented in artificial intelligent systems directly. Nevertheless, it can be represented indirectly by means of constructing adequate discrete mathematical models of existing metaphysical systems worthy of being represented. Not all details of the history of philosophy but at least all famous metaphysical doctrines and noteworthy opinions of prominent philosophers are to be represented at the level of artificial language of corresponding discrete mathematical model.

\section{References}

Aquinas, T. (1928). The Summa contra Gentiles. The Third Book: Providence. Part II. Chapters LXXXIV - CLXIII (Literally Translated by the English Dominican 
Fathers from the Latest Leonine Edition). London, Burns Oates \& Washbourne Ltd, $218 \mathrm{p}$.

Aquinas, T. (1994). The Summa Theologica. V. II. In: Great Books of the Western World. V. 18: Aquinas II. Chicago, Auckland, London, Madrid, Encyclopaedia Britannica, Inc., 1085 p.

Aristotle (1994). The Works of Aristotle. V.I. In: Great Books of the Western World. Vol. 7. Chicago, Auckland, London, Madrid, Manila, Paris, Encyclopedia Britannica, Inc. $726 \mathrm{p}$.

Berkeley, G. (1994). The Principles of Human Knowledge. In: Great Books of the Western World. V. 33: Locke, Berkeley, Hume, Chicago, Auckland, London, Madrid, Encyclopaedia Britannica, Inc., 403-444.

Béziau, J.-Y. (2012a). The New Rising of the Square of Opposition. In: Around and Beyond the Square of Opposition, Basel, Birkhäuser, 3-19.

Béziau, J.-Y. (2012b). The Power of the Haxagon. In: Logica Universalis, 6 (1-2), $1-43$.

Béziau, J.-Y. (2017). Universal Logic. Available at: http://www.jyb-logic.org/ papers/LogicaYB94 \%20-\%20Beziau.pdf (accessed 14 August 2017).

Blanché, R. (1957). On Structuration of the Tables of/for Binary Interpropositional Connectives [Sur la structuration du tableau des connectifs interpropositionnels binaires]. In: Journal of Symbolic Logic, 22 (1), 17-18.

Blanché, R. (1966). Intellectual Structures. Essay on Systematic Organization of Concepts [Structures intellectuelles. Essai sur l'organisation systématique des concepts], Paris, Vrin, 151 p.

Bull, R., Segerberg, K. (1984). Basic Modal Logic, In D. Gabbay, F. Guenthner (eds.). In: Handbook of Philosophical Logic, vol. II: Extensions of Classical Logic. Dordrecht, Reidel Publishing Company, 1-88.

Descartes, R. (1994a). Rules for the Direction of the Mind. In: Great Books of the Western World. V. 28: Bacon. Descartes. Spinoza. Chicago, Auckland, London, Madrid, Encyclopedia Britannica, Inc., 223-262.

Descartes, R. (1994b). Discourse on the Method of Rightly Conducting the Reason. In: Great Books of the Western World. V. 28: Bacon. Descartes. Spinoza. Chicago, Auckland, London, Madrid, Encyclopedia Britannica, Inc., 265-291.

Descartes, R. (1994c). Meditations on First Philosophy. In: Great Books of the Western World. V. 28: Bacon. Descartes. Spinoza. Chicago, Auckland, London, Madrid, Encyclopedia Britannica, Inc., 295-329. 
Descartes, R. (1994d). Meditations on First Philosophy. In: Great Books of the Western World. V. 28: Bacon. Descartes. Spinoza. Chicago, Auckland, London, Madrid, Encyclopedia Britannica, Inc., 330-519.

Hume, D. (1977). A Treatise of Human Nature, London, Dent, New York, Dutton, 320 p.

Hume, D. (1994). An Inquiry Concerning Human Understanding. In: Great Books of the Western World. V. 33: Locke, Berkeley, Hume, Chicago, Auckland, London, Madrid, Encyclopaedia Britannica, Inc., 451-509.

Kelsen, H. (1945). General Theory of Law and State, Cambridge, Harvard University Press, 516 p.

Kelsen, H. (1959). On the Basic Norm. In: California Law Review, 47 (1), 107-110.

Kelsen, H. (1974). Essays in Legal and Moral Philosophy, Dordrecht, Boston, Reidel, 300 p.

Kelsen, H. (1991). General Theory of Norms, Oxford, Clarendon Press, New York, Oxford University Press, 465 p.

Kelsen, H. (1992). Introduction to the Problems of Legal Theory, Oxford, Clarendon Press, New York, Oxford University Press, 171 p.

Kelsen, H. (2002). Pure Theory of Law, Union, NJ, Law Book Exchange, 356 p.

Kripke, S.A. (1963). Semantical Analysis of Modal Logic I. Normal Modal Propositional Calculi. In: Zeitschrift fur mathematische Logik und Grundlagen der Mathematik, 9 (5-6), 67-96.

Kripke, S.A. (1965). Semantical Analysis of Modal Logic II: Non-Normal Modal Propositional Calculi. In: The Theory of Models (Proceedings of the 1963 International Symposium at Berkley). Amsterdam, North-Holland, 206-220.

Leibniz, G.W. (1903). Generales Inquisitiones de Analysi Notionum et Veritatum. In: Opuscules et Fragments Inédits de Leibniz: extraits de la Bibliothèque royale de Hanovre. Par Louis Couturat, Chargé de Cours a l'Université de Toulouse. Paris, Alcan, 356-399.

Leibniz, G.W. (1951). Theodicy: Essays on the Goodness of God, the Freedom of Man, and the Origin of Evil. London, Routledge and Kegan Paul, 448 p.

Leibniz, G.W. (1971). Elementa Juris Naturalis, In Leibniz, G. W. Philosophishe Schriften. Erster Band: 1663-1672, Berlin, Akademie-Verlag, 431-485.

Leibniz, G.W. (1997). New essays on human understanding, Cambridge, New York, Cambridge University Press, 580 p.

Lobovikov, V.O. (2016a). Aksiomatizațî́a filosofskoǐ èpistemologii [An Axiomatization ofPhilosophicalEpistemology].In: VestnikTomskogogosudarstvennogo 
universiteta. Filosofîa. Sotsiologîa. Politologii a [Herald of Tomsk State University. Philosophy. Sociology. Political Studies], 36 (4), 69-78. DOI: 0.17223/1998863X/36/7

Lobovikov, V.O. (2016b). Aksiomatizatsîia èpistemologii kak sredstvo èksplikatsii teorii prava: «Digesty» IUstiniana i problema odnorodnosti estestvennogo prava [Axiomatizing Epistemology as a Means for Explicating Law Theory: "Digesta" Iustiniani and a Problem of Homogeneity of the Natural Law]. In: Nauchnyizhurnal “Diskurs-P" [Scientific Journal "Discourse-P”], 24 (3), 48-60.

Lobovikov, V.O. (2016c). Dokazatel'stvo teoremy o kalokagatii v aksiomaticheskor̆ sisteme filosofskor èpistemologii (Optimizm i predustanovlennaîa garmoniîa: ot drevnegrecheskoĭ i rannekhristianskoĭ filosofii k A.Ė. SHeftsberi, G. V. Leǐbnit su i K. Gëdeliu.) [Proving a Theorem of Kalokagathia in Axiomatic System of Philosophical Epistemology (Optimism and Pre-Established Harmony: from Ancient Greek Philosophy and Early Christian One, to A.A. Shaftesbury, G.W. Leibniz, and K. Gödel)]. In: Nauchnyı zhurnal "Diskurs-P" [Scientific Journal "Discourse-P"], 24 (4), 256-264.

Lobovikov, V.O. (2016d). Aksiomaticheskoe opredelenie sfery adekvatnosti ratsionalisticheskogo optimizma G.V. Leübnitsa, D. Gil'berta i K. Gëdelia [An Axiomatic Definition of the Domain of Adequateness of the Rationalistic Optimism of G.W. Leibniz, D. Hilbert, and K. Gödel]. In: Sibirskiu filosofskiǔ zhurnal [Siberian Journal of Philosophy], 14 (4), 69-81.

Lobovikov, V.O. (2016e). Utochnenie formulirovki i variant resheniia problemy èkvivalentnosti deonticheskikh, aleticheskikh i aksiologicheskikh modal'nosteř $\mathrm{s}$ pomoshch'iu aksiomaticheskoĭ sistemy filosofskor èpistemologii [An Explication of Formulation and an Option of Solution of the Problem of Equivalence of Deontic, Alethic, and Axiological Modalities by Means of Axiomatic System of Philosophical

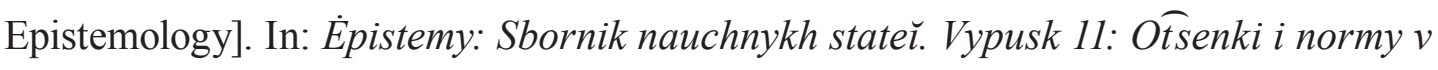
strukture ratsional'nogo znaniīa [Episteme: A Collection of Scientific Papers. Issue 11: Values and Norms in Structure of Rational Knowledge]. Yekaterinburg, Izdatel'skopoligraficheskoe predpriiatie «Maks-Info» [Publishing Enterprise "Max-Info"], $48-67$.

Lobovikov, V.O. (2017a). Deduktivnoe dokazatel'stvo èkvivalentnosti istinnosti i poleznosti apriornogo znaniia v aksiomaticheskoř sisteme èpistemologii [A Deductive Proof of Equivalence of Truthfulness and Usefulness of A-Priori Knowledge in Axiomatic System of Epistemology]. In: Sibirskiu filosofskiu zhurnal [Siberian Journal of Philosophy], 15 (2), 40-52. 
Lobovikov, V.O. (2017b). An Important Problem of Homogeneity of the Natural Law and Solving it by Means of an Axiomatic System of Philosophical Epistemology. In: XXVIII World Congress on the Philosophy of Law and Social Philosophy "Peace Based on Human Rights", School of Law of the University of Lisbon, July 16 to 21, 2017, Lisbon, University of Lisbon, 653-654.

Lobovikov, V.O. (2017c). An Important Problem of Homogeneity of the Natural Law and Solving it by Means of an Axiomatic System of Philosophical Epistemology. Available at: http://ivr2017lisbon.org/images/Congresso/papers/Vladimir\%20Lobovikov $\% 20$-on $\% 20$ the $\% 20$ Natural-Law-Homogeneity $\% 20$ Problem $\% 20$ and $\% 20$ Solving $\% 20$ It.pdf (accessed 14 August 2017).

Locke, J. (1994). An Essay Concerning Human Understanding. In: Great Books of the Western World. V. 33: Locke, Berkeley, Hume, Auckland, London, Madrid, Encyclopaedia Britannica, Inc., 85-395.

Mach, E. (1914). The Analysis of Sensations and the Relation of the Physical to the Psychical, Chicago, London, Open Court Publishing Company, 380 p.

Mill, J.-St. (1996). An Examination of Sir William Hamilton's Philosophy and of The Principal Philosophical Questions Discussed in his Writings, London, Routledge, 625 p. Mill, J.-St. (1994). Utilitarianism. In: Great Books of the Western World. V. 40: American State Papers, The Federalist, J. S. Mill. Chicago, Auckland, London, Madrid, Encyclopaedia Britannica, Inc., 445-476.

Moore, G.E. (2004). Principia Ethica, Mineola, NY, Dover Publications, 232 p.

Plato. (1994). The Dialogues. In: Great Books of the Western World. V. 6: Plato. Chicago, Auckland, London, Madrid, Encyclopedia Britannica, Inc., 814 p.

Popper, K. (1989). Conjectures and Refutations: the Growth of Scientific Knowledge, London, New York, Routledge, 431 p.

Popper, K. (1992). The Logic of Scientific Discovery, London, New York, Routledge, 479 p.

Priest, G. (1992). What is a Non-Normal World? In: Logique et Analyse, 139-140, 291-302.

Priest, G. (2008). An Introduction to Non-Classical Logic: From If to Is, 2nd Edition, Cambridge, New York, Cambridge University Press, 643 p.

Spinoza, B. (1994). Ethics. In: Great Books of the Western World. V. 28: Bacon. Descartes. Spinoza. Chicago, Auckland, London, Madrid, Encyclopedia Britannica, Inc., 583-697.

Wittgenstein, L. (1994). Tractatus logico-philosophicus, London, New York, Routledge, 89 p. 


\title{
Синтез нормальных и ненормальных модальных логик \\ в аксиоматической системе философской эпистемологии \\ моделируемый логическим квадратом \\ и гексагоном оппозиции
}

\author{
В.О. Лобовиков \\ Институт философии и права УрО РАН \\ Россия, 620990, Екатеринбург, ул. Софьи Ковалевской, 16
}

Цель статьи - решение трудной проблемь раџионального объединения ошеломляюще огромного количества качественно различных модальных логик. Для достижения этой цели используются искусственные языки символической логики и методология аксиоматики. Поэтому систематически используется метод конструирования и изучения формальных логических выводов в исследуемой аксиоматической системе. Новым нетривиальным научным результатом этой работы является изобретение и детальная разработка до сих пор не исследованной аксиоматической системы эпистемологии, объединяющей нормальные и ненормальные логики. Важными областями приложения нетривиальных абстрактно-теоретических принцииов, обоснованных в этой статье являются история философии и систематическая философия, формальная этика и формальная эстетика, философская эпистемология и аналитическая теология, философия права и философия науки. Используя вышеуказанные средства, автор пришел к следующему основному выводу. Знаменитые философские принципь утилитаризма, гедонизма, оптимизма, прагматизма, фидеизма, фальсифицируемости, верифицируемости, «Гильотина Юма», «анти-натурализм» ... имеют не абсолютно неопределенную (неограниченную), а вполне определенную (ограниченную) сферу уместной применимости; точное формальное определение границы упомянутой сферы релевантности является аксиоматическим; оно представлено и обсуждается в данной статье. Этот общий вывод экземплифицируется в тексте серией частных выводов, касающихся уточнения и прояснения специфических философских идей и принципов, например, принципа калокагатии. В заключении автор делает вывод что, конструирование и исследование аксиоматических систем универсальной философской эпистемологии необходимо для адекватного представления человеческого знания в искусственных интеллектуальных системах, например, в автономных роботах с элементами искусственно интеллекта.

Ключевые слова: нормальная, ненормальная, модальная, универсальная, логика, a-priori, a-posteriori, знание, аксиоматическая система, квадрат-и-гексагон-оппозиции.

Научная специиальность: 09.00.00 - философские науки. 